\title{
Battle fatigue and Saturday night on call
}

Don Krieger, PhD

Neurology ${ }^{\circledR} 2018 ; 91: 625-626$. doi:10.1212/WNL.0000000000006249

\section{Battle fatigue}

The surgeon carves, dissects, sears the bleeding.

The anesthetist: numbness, paralysis, stupor.

My part: to hear and report

each limb's electric murmurs,

the brain's muffled replies,

mixed with the whine

of machines, arrogance, fear. We fight for

normal life on waking.

We trust normal will return for us.

They are out there, our charges,

ten thousand who woke well,

those who did not. I don't recall

their faces, just the smell

of blood and burning,

the urgent charge, uphold life,

sick wonder when the lamp goes dark, why did I

have to see that?

\section{Saturday night on call}

A sheriff guards the operating room. Inside we fight.

Her neck was broken in a brawl. She thrashes and spits as we hold her shoulders and head still, work to

realign the bones,

constantly checking, dreading the worst,

blunt silence, slack body. Hours later with neck straight, flipped on her belly, moving arms and legs before she sleeps, I step out for a breath. The surgeon is at the scrub sink, She'll just kill someone else.

That may be, I say, but we won't have killed her. It's been many years. I still dread and hope for her, and I treasure the stubborn skill of that surgeon.
Correspondence

Dr. Krieger

kriegerd@upmc.edu

\section{MORE ONLINE}

ค Audio

Listen to Dr. Krieger read this poem.

NPub.org/pi5psv 


\section{References}

1. Krieger D, Burk G, Sclabassi RJ. Neuronet: a distributed real-time system for monitoring neurophysiologic function in the medical environment. IEEE Computer 1991; $24: 45-55$.
2. Simon R, Krieger D, Znati T, Lofink R, and Sclabassi RJ. MultiMedia MedNet: a medical collaboration and consultation system. IEEE Computer 1995;28:65-73.

3. Krieger D, Sclabassi RJ. Time varying evoked potentials. J Med Eng Technol 1994;18:96-100.

4. Krieger D, Onodipe S, Charles PJ, Sclabassi RJ. Real time signal processing in the clinical setting. Ann Biomed Eng 1998;269:462-472. 


\title{
Neurology
}

\author{
Battle fatigue and Saturday night on call \\ Don Krieger \\ Neurology 2018;91;625-626 \\ DOI 10.1212/WNL.0000000000006249
}

This information is current as of September 24, 2018

\section{Updated Information \& Services}

\section{References}

Subspecialty Collections

Permissions \& Licensing

\section{Reprints}

including high resolution figures, can be found at: http://n.neurology.org/content/91/13/625.full

This article cites 4 articles, 0 of which you can access for free at: http://n.neurology.org/content/91/13/625.full\#ref-list-1

This article, along with others on similar topics, appears in the following collection(s):

All clinical neurophysiology

http://n.neurology.org/cgi/collection/all_clinical_neurophysiology

Brain trauma

http://n.neurology.org/cgi/collection/brain_trauma

Evoked Potentials/Somatosensory

http://n.neurology.org/cgi/collection/evoked_potentials-somatosensory Spinal cord trauma

http://n.neurology.org/cgi/collection/spinal_cord_trauma

Spinal cord trauma; see Trauma/spinal cord trauma

http://n.neurology.org/cgi/collection/spinal_cord_trauma-see_trauma-s pinal_cord_trauma

Information about reproducing this article in parts (figures,tables) or in its entirety can be found online at:

http://www.neurology.org/about/about_the_journal\#permissions

Information about ordering reprints can be found online:

http://n.neurology.org/subscribers/advertise

Neurology ${ }^{\circledR}$ is the official journal of the American Academy of Neurology. Published continuously since 1951, it is now a weekly with 48 issues per year. Copyright (O) 2018 American Academy of Neurology. All rights reserved. Print ISSN: 0028-3878. Online ISSN: 1526-632X.

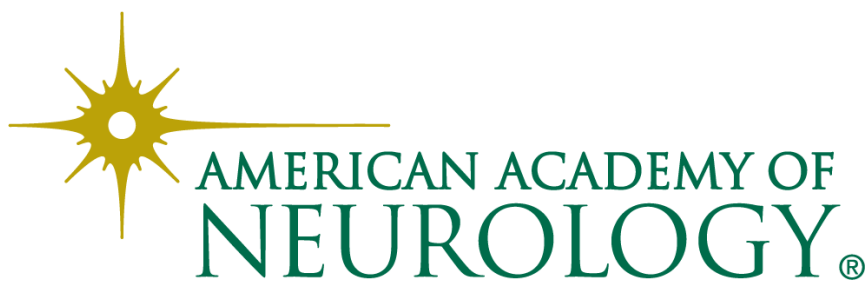

